\title{
Correction of Adolescent Tibia Vara by Ilizarov External Fixator
}

\author{
KAMAL A.M. EL-GAFARY, M.D.*; MOHAMED M. ABD EL-HAMID MORSY, M.D.*; \\ WAEL YOUSIF EL-ADLY, M.D.* and SHADY F. MAHMOUD, M.Sc.**
}

The Department of Orthopedics \& Traumatology, Faculty of Medicine, Assiut University* and The Department of Orthopaedic \& Trauma Surgery, El-Eman Hospital**

\begin{abstract}
Background: Tibia vara, also termed as blount disease. Blount described a group of children who had an onset of varus deformity of the proximal part of the tibia in later childhood or adolescence, a condition that he described as adolescent tibia vara. It is characterized by proximal varus angulation of the tibia associated with medial metaphyseal depression, internal torsion of the tibia and genu recurvatum, growth retardation, and a propensity toward additional progression.
\end{abstract}

The Ilizarov external fixation and principles provides gradual correction of the angulation, rotation, translation, and length discrepancy, thus minimizing complications.

Aim of Study: The purpose of the current study is to evaluate the results of management of adolescent tibia vara using Ilizarov external fixator.

The morphological outcome will be evaluated radiologically to determine the amount of correction using different angles, axes and complications.

Patients and Methods: Ten were treated lower limbs of 7 patients with tibia vara were treated with application of Ilizarov External Fixator (IEF), between 2014 and 2017 at Ilizarov Unit, Assiut University Hospital. Their mean age was 14 years (range 11-16.8 years). Three patients were males and four patients were females. The right side was affected in one case and the left side in 3 and bilateral in 3 . Their main complaint was pain on walking and cosmoses. The patients were subjected to clinical assessment, including local examination as analysis of gait including lateral thrust of the knee and intoeing was done. Followed by AP radiological examination of both lower limbs in standing position for the involved limb. CT scanogram was done for lower limb discrepancy. The residual deformity was reported in 3 extremities. They were above 10 years old, obese, with past history of pervious failed trials for correction. They presented also with decreased knee range of motion. They still satisfied till last follow-up. The varus deformity was associated with shortening in 4 cases with 7 lower limb deformities had shortening ranged from 3$5 \mathrm{~cm}$ with mean $4 \mathrm{~cm}$, the shortening was corrected with residual

Correspondence to: Dr. Kamal Ahmed Mohamed El-Gafary, The Department of Orthopedics \& Traumatology, Faculty of Medicine, Assiut University limb length difference $( \pm 5 \mathrm{~mm})$, with procurvatum in 6 cases, with recurvatum in 3 cases and with internal rotation in all patients except one. Ilizarov external fixator was applied and gradual correction was performed. Varus tibiofemoral angle, procurvatum, recurvatum, lower limb discrepancy, internal tibia1 torsion and knee range of motion were measured preoperatively; post-operatively and at last follow-up.

Results: The mean time for deformity correction and Ilizarov stabilization was 14 weeks (range 12-30 weeks), including 2 weeks of dynamization. The mean deformity of $27.6^{\circ}$ varus (range, $19.2^{\circ}-35.9^{\circ}$ ) was corrected to $2.8^{\circ}$ valgus (range $3^{\circ}-7.51^{\circ}$ ) and $22.2^{\circ}$ internal rotation (range $0^{\circ}-49^{\circ}$ ) was corrected $3^{\circ}$ extenal rotation (range $0^{\circ}-8^{\circ}$ ), the mean $7.2^{\circ}$ procurvatum angle $\left(\right.$ range $\left.0^{\circ}-25^{\circ}\right)$ was $\left(\right.$ range $0^{\circ}-7^{\circ}$ ) and $12.4^{\circ}$ recurvatum angle (range, $0^{\circ}-28^{\circ}$ ) was changed to $3.5^{\circ}$ (range, $15^{\circ}$ recurvatum $-6^{\circ}$ procurvatum). The mean knee range of motion was $126.55^{\circ}$ (range $95^{\circ}-148^{\circ}$ ), became $129.2^{\circ}$ (range, $85^{\circ}-145^{\circ}$ ). The mean shortening of $4.5 \mathrm{~cm}$ (range $3.5-5.5 \mathrm{~cm}$ ) the shortening had been corrected with residual limb length difference $( \pm 5 \mathrm{~mm})$ in all patients. Construct modification had to be done in 8 cases without anaesthia, and other additional procedures were done to treat complications of the frame in the same operation time.

Wire site inflammation was common and pin tract infection was common and pin tract infection was treated in 8 cases using oral or parentral antibiotics. However there was a case of deep infection that needs debridement. We reported residual deformity in 3 patients, although they were satisfied. There were no neurovascular complications, delayed union or non unions.

Conclusion: Gradual correction of severe adolescent tibia vara by Ilizarov external fixator is economic, effective, accurate and safe. Limitation of the study is short term follow-up and relatively small sample size.

Key Words: Tibia vara-Ilizarov external fixator.

\section{Introduction}

TIBIA vara, also termed as Blount disease. Blount described a group of children who had an onset of varus deformity of the proximal part of the tibia in later childhood or adolescence, a condition that he described as adolescent tibia vara. It is charac- 
terized by proximal varus angulation of the tibia associated with medial metaphyseal depression, internal torsion of the tibia and genu recurvatum, growth retardation, and a propensity toward additional progression [1].

The condition may be unilateral or bilateral. For adolescent tibia vara osteotomy is indicated to correct progressive deformity, to equalize limb lengths, and to alleviate patient discomfort $[2,3]$

\section{Patients and Methods}

After approval of the Ethical Committee of Assiut University Hospital, this study was done on 10 deformities of tibias in 7 patients treated by Ilizarov circular external fixator between April 2014 and April 2017 in Ilizarov Unit, Orthopedic Department in Assiut University Hospital.

The patients included in this work aged between 11 years and 17 years with adolescent tibia vara with exclusion of other types of tibia vara; as Infantile Blount's disease (from 1-3 years) and Juvenile Blount's disease (from 4-10 years).

\section{Pre-operative assessment:}

Pre-operative assessment was done by taking history, examination; as general and local examination, analysis of the deformity; as tibial torsion and measurement of limb length discrepancy, preoperative radiological assessment as using anteroposterior standing films were taken to the whole lower limb (HKA: Hip knee ankle radiograph to measure coronal plane mal-alignment) the following measurements were done in all patients:

1-Metaphyseal-diaphyseal angle: The metaphyseal-diaphyseal angle is the angle created by the intersection of a line drawn through the transverse plane of the proximal tibial metaphysis and the line drawn perpendicular to the long axis of the tibial diaphysis.

2-Mechanical tibiofemoral axis (mechanical axis): Drawing a line from the center of the femoral head to the center of the ankle. This line should normally pass through the medial tibial spine or between the tibial spines.

3- Medial prOximal Tibial Angle (MPTA): Being the angle between the mechanical axis line of the tibia and the tibial plateau line angle. Normally, this angle measures $87^{\circ}$ with a range of $86^{\circ}$ to $89^{\circ}$

4- Posterior proximal tibial angle: A line is drawn in the sagittal plane from the junction of the anterior and second fifth of the proximal tibial joint line to the point center on the distal tibial joint line. The posterior proximal tibial angle (PPTA) is measured (average normal, $80 \mathrm{de}$ grees, range, 77 to 84 degrees).

5- Joint Line Congruence Angle (JLCA): An angle formed between joint orientation lines on opposite sides of the knee joint this line is normally parallel.

6- Tibial slope: The line tangential to the anterior aspect of the distal femur and the anterior tibia should be collinear for the knee to have full extension. The tibial plateau has a normal posterior slope, measuring $8^{\circ}-12^{\circ}$.

Osteotomy consideration is essential preoperative planning for successful correction of tibia vara deformity by Ilizarov frame by determining level of osteotomy and type of osteotomy, Hinge placement; as position and type, then preassembly of the Ilizarov frame was carried out a day before the operation to shorten the operative time.

Intra-operative technique of correction of tibial deformities:

In adolescent, the assembled frame was made up of three rings, one proximal and two distal block which consists of two rings connected by three rods; the proximal two rings are connected by appropriate as was planned preoperative two hinges and posteromedial distraction rod to gain more stable frame. The safe anatomic location for insertion of wires and half-pins must be minded during insertion. The patient lied supine on orthopedic table. Under general or spinal anesthesia the operated leg was raised to be free by putting special blocks behind the ankle and distal thigh. A cuff of pneumatic tourniquet was wrapped on upper thigh. Sterilization rules was followed quietly. The limb was elevated for few minutes and tourniquet was raised.

Under tourniquet, small posterolateral incision was done at the junction of middle and distal third of the fibula. Separate the soft tissues by artery forceps. Expose the bone by fine periosteal elevator. Replacement the elevator by wide curved retractor to protect the surrounding soft tissues. Fibular osteotomy was done, tibial osteotomy: The tibial osteotomy was now performed just distal to the tibial tubercle. To perform a proper osteotomy preliminary weakness of the bone by drill bit $4.5 \mathrm{~mm}$, one must use an osteotome that is $2-3 \mathrm{~mm}$ thick and $8-10 \mathrm{~mm}$ wide. The osteotomy was started 
at the edge of the tibial crest and continued in all directions.

Close the wound and compress it by a sterilized gauze bandage. After this, the tourniquet was released.

The already sterilized frame was drawn on the leg and then the correct size and length was checked. The height at which the proximal ring was applied corresponds to the upper end of head of fibula. The distal ring laid just proximal to the lateral malleolus. Level of intermediate ring or rings may differ, usually few centimeters from corticotomy site or sites. Care was taken to leave $2-3 \mathrm{~cm}$ between the skin surface and the inner circumference of each ring. Centralization of the frame was achieved by transverse wire on the proximal ring just proximal to the head of fibula parallel to the knee joint line and a transverse wire on the proximal ring just proximal to the head of fibula parallel to the knee joint line and a transverse wire on the distal ring parallel to the ankle joint.

Check the position by portable X-ray or image intensifier. If it was well and good, complete the fixation. Fixation of the proximal ring was done by anteromedial or posteromedial half pins. Fixation of the fibular head by wire gives excellent stability to the whole system especially in cases that need more distraction. Intermediate ring or rings must be adjusted to be perpendicular on long axis of the shaft and usually fixed by transverse wire and anteromedial half pin. The distal ring was fixed by two wires oblique on the transverse, one passes from the lateral malleolus directed anteromedial and the other passes in front of the bundle from the medial directed anterolateral. At the end, stability of the frame was checked. It must be well and good.

Assurance anteroposterior and lateral radiographs were taken before the patient leaves the operating room, dressing around the pins and wires.

\section{Post-operative management during deformity correction:}

X-ray was done on the frame for evaluation of the pin or wire position, the hinge position and the osteotomy sites, after one week of distraction Xray was done. This can show a gap between the bone fragments that corresponded to the distraction. Monthly visits was recommended during correction of deformity to assess the amount of deformity correction after obtaining the desired amount of correction. Clinical and radiological assessment to evaluate regenerated bone, angles. Sometimes we may advise to slow down the speed of distraction depending on the quality of bone formation in the distraction gap. The following points were addressed: Observation for deviation or angulation of bone fragments, checking the tension of the wires that may need re-tensioning, observation any infection at the site of wire and pins and advice the patients for cleaning of these sites and prescribe antibiotics, the complications were classified into mild, moderate or severe according to Saleh and Burton, Checking the range of motion of knee joint, checking any new joint stiffness in the knee joint and deal with it by frequency of physiotherapy, checking the space between the rings and the skin that may reduce and may cause pressure on the skin when foot edema occur, that condition may need readjustment of the frame and then after full correction of the deformity (clinically and radiologically): The hinges were replaced by rods to allow complete weight bearing and clinical visit every two weeks.

It was a routine to check the quality of the maturing regenerate with X-ray. The patient's weight bearing should increase steadily during this period with satisfactory appearance of the regenerate calcification and its complete recanalization. The formation of cortex was seen at this stage dynamization of the frame was done by loosening the nuts at the sides of connecting rods attachments this dynamizes the immobilized bone fragments and the regenerate between them and the patients continue to apply axial loading to the bone. The complications were considered mild when managed by simple conservative measures or minimal for a degree that not affect the end results, moderate complications that could be corrected by surgical intervention and the severe one that could not be managed during treatment, affects the end results and needs another surgical measures later on. Pin tract infections, are considered the most common complication in this line of treatment that were graded according to Checketts and Otterburn classification; after maturing of regeneration, the Ilizarov external fixator was removed according to technique of Ilizarov fixator removal.

\section{Statistical analysis:}

Data was analyzed using Statistical Package for Social Sciences (SPSS) version 21.0, the $p$ value $>0.001$ level was used as the cut off value for statistical significance, count and percentage were used for describing and summarizing qualitative data, arithmetic mean and Standard Deviation (SD) were used as measures of central tendency 
and dispersion for quantitative data respectively, the median was used for measurement of central dispersion when the SD is more the mean, Univar rate analysis for clinical and radiological nonparametric results was carried out using paired sample $t$-test.

\section{Results}

In this study, ten knees with varus deformity in 14 limbs were treated by Ilizarov circular external fixator, the age was ranged between 11 years to 17 years, the mean was 14 years, three patients were males and four patients were females, the right lower limb was affected in one case. The left lower limb was affected in 3 cases. Both limbs were affected in 3 cases, the mean magnitude of mechanical tibiofemoral deformity was $27.6^{\circ}$ varus (range $19.2^{\circ}-35.9^{\circ}$ ) that was corrected to $2.8^{\circ}$ varus (range, $0.3^{\circ}-7.51^{\circ}$ ), the mean of internal torsion was $22.2^{\circ}$ (range, $0^{\circ}-49^{\circ}$ ) which was corrected to $3^{\circ}$ external torsion (range, $0^{\circ}-8^{\circ}$ ). The mean of $9.6^{\circ}$ procurvatum angle (range $2.7-18.7^{\circ}$ ) was changed to $10.2^{\circ}$ (range, $\left.7.9-15.6^{\circ}\right)$.

Clinical results: The clinical results of this work were evaluated regarding the following parameters: The degree of deformity correction, healing duration, range of motion, the gained length, the occurrence of complications and the functional results. The healing duration: The mean time for deformity correction was 14 weeks (range, 12-30 weeks), including 2 weeks of dynamization, The range of motion: The mean range knee range of motion was $80^{\circ}$ (range, $65^{\circ}-140^{\circ}$ ), became $70^{\circ}$ (range, $0^{\circ}-140^{\circ}$ ), the gained length: In this study 4 cases with 7 lower limb deformities had shortening ranged from $3-5 \mathrm{~cm}$ with mean $4 \mathrm{~cm}$, the short- ening was corrected with residual limb length difference $( \pm 5 \mathrm{~mm})$, complications: In the current study there were ten complications: Pin track infection: Wire site inflammation was the commonest complication faced in our study. Seven of them were superficial infection (type 2 according to Checketts and Otterburn classification), they were with local cleaning measures and oral antibiotics. One case was deep soft tissue infection (type 6 according to Checketts and Otterburn classification) which needed surgical debridement, overcorrection: It occurred in one case which was treated by readjustment of the frame in varus direction, knee stiffness: Occurred in one case as flexion deformity which was corrected by physiotherapy and extension was improved, functional results: In cases with angular deformities of tibia according to Huang we classified the results as following: Excellent results: Less than $5^{\circ}$ of residual deformity and no complications. Good results: Less than $15^{\circ}$ residual deformity and only minor complications which did not affect the outcome or require extensive intervention. Fair results: Less than $30^{\circ}$ residual deformity and serious complications. Complications that were either major and temporary, or minor and permanent were considered to be serious, those patients who needed subsequent operation to achieve satisfactory results were grouped in this class. Poor results: More than $30^{\circ}$ of residual deformity and severe complications requiring major surgery or resulting in a major permanent sequel. We had 7 excellent cases, 2 good cases, no fair cases and no poor case.

Radiological results: Nine cases were grade II callous formation while, one case was grade I.

Pre-operative and post-operative angles values (Tables 1,2):

Table (1): The mean of pre-operative and post-operative measured angles in X-ray.

\begin{tabular}{lccc}
\hline Parameters & Pre-operative & Post-operative & $p$-value \\
\hline m TFA (MA) & $27.1 \pm 8.1$ & $2.8 \pm 1.9$ & $<0.001 *$ \\
MPTA & $73.6 \pm 13.38$ & $87.6 \pm 0.92$ & $<0.001 *$ \\
JLCA & $5.6 \pm 0.99$ & $1.12 \pm 0.65$ & $<0.001 *$ \\
PPTA & $80.4 \pm 5.62$ & $79.1 \pm 3.39$ & $<0.001 *$ \\
Tibial Slope & $9.65 \pm 0.32$ & $10.82 \pm 4.7$ & $<0.001 *$ \\
\hline
\end{tabular}

Data are presented as mean \pm standard deviation.

* High statistical significant difference, $p<0.001$. 
Table (2): The pre-operative and post-operative measured angles in X-ray.

\begin{tabular}{|c|c|c|c|c|c|}
\hline & m TFA & MPTA & JLCA & PPTA & Tibil slope \\
\hline $\begin{array}{c}\text { Case number (1): } \\
\text { Pre-operative } \\
\text { Post-operative }\end{array}$ & $\begin{array}{l}15.69 \\
0.3\end{array}$ & $\begin{array}{l}65.1 \\
86.6\end{array}$ & $\begin{array}{l}4.1 \\
0.2\end{array}$ & $\begin{array}{l}71.3 \\
77.6\end{array}$ & $\begin{array}{l}18.7 \\
12.4\end{array}$ \\
\hline $\begin{array}{c}\text { Case number (2): } \\
\text { Pre-operative } \\
\text { Post-operative }\end{array}$ & $\begin{array}{l}21.03 \\
3.1\end{array}$ & $\begin{array}{l}72.7 \\
88.1\end{array}$ & $\begin{array}{l}6.1 \\
1.5\end{array}$ & $\begin{array}{l}82.8 \\
78.4\end{array}$ & $\begin{array}{l}7.2 \\
11.6\end{array}$ \\
\hline $\begin{array}{c}\text { Case number (3): } \\
\text { Pre-operative } \\
\text { Post-operative }\end{array}$ & $\begin{array}{l}21.4 \\
2.1\end{array}$ & $\begin{array}{l}69.3 \\
87.3\end{array}$ & $\begin{array}{l}5.2 \\
0.8\end{array}$ & $\begin{array}{l}75.8 \\
79.8\end{array}$ & $\begin{array}{l}14.2 \\
10.2\end{array}$ \\
\hline $\begin{array}{c}\text { Case number (4): } \\
\text { Pre-operative } \\
\text { Post-operative }\end{array}$ & $\begin{array}{l}20.1 \\
5.8\end{array}$ & $\begin{array}{l}72.2 \\
88.7\end{array}$ & $\begin{array}{l}6.7 \\
1.6\end{array}$ & $\begin{array}{l}83.2 \\
79.2\end{array}$ & $\begin{array}{l}6.8 \\
10.8\end{array}$ \\
\hline $\begin{array}{c}\text { Case number (5): } \\
\text { Pre-operative } \\
\text { Post-operative }\end{array}$ & $\begin{array}{l}22.2 \\
1.3\end{array}$ & $\begin{array}{l}66.3 \\
86.4\end{array}$ & $\begin{array}{l}4.3 \\
0.2\end{array}$ & $\begin{array}{l}72.7 \\
77.7\end{array}$ & $\begin{array}{l}17.3 \\
12.3\end{array}$ \\
\hline $\begin{array}{c}\text { Case number (6): } \\
\text { Pre-operative } \\
\text { Post-operative }\end{array}$ & $\begin{array}{l}34.7 \\
2.5\end{array}$ & $\begin{array}{l}71.1 \\
85.1\end{array}$ & $\begin{array}{l}5.5 \\
1.1\end{array}$ & $\begin{array}{l}84.9 \\
81.9\end{array}$ & $\begin{array}{l}8.1 \\
5.1\end{array}$ \\
\hline $\begin{array}{c}\text { Case number (7): } \\
\text { Pre-operative } \\
\text { Post-operative }\end{array}$ & $\begin{array}{l}27.6 \\
7.77\end{array}$ & $\begin{array}{l}75.5 \\
87.7\end{array}$ & $\begin{array}{l}5.8 \\
1.3\end{array}$ & $\begin{array}{l}77.7 \\
82.1\end{array}$ & $\begin{array}{l}12.3 \\
7.9\end{array}$ \\
\hline $\begin{array}{c}\text { Case number (8): } \\
\text { Pre-operative } \\
\text { Post-operative }\end{array}$ & $\begin{array}{l}30.1 \\
1.9\end{array}$ & $\begin{array}{l}68.6 \\
86.8\end{array}$ & $\begin{array}{l}4.9 \\
0.6\end{array}$ & $\begin{array}{l}87.3 \\
74.4\end{array}$ & $\begin{array}{l}2.7 \\
15.6\end{array}$ \\
\hline $\begin{array}{c}\text { Case number (9): } \\
\text { Pre-operative } \\
\text { Post-operative }\end{array}$ & $\begin{array}{l}32.8 \\
3.3\end{array}$ & $\begin{array}{l}73.3 \\
88.3\end{array}$ & $\begin{array}{l}6.4 \\
1.6\end{array}$ & $\begin{array}{l}83.5 \\
79.8\end{array}$ & $\begin{array}{l}6.5 \\
10.2\end{array}$ \\
\hline $\begin{array}{c}\text { Case number (10): } \\
\text { Pre-operative } \\
\text { Post-operative }\end{array}$ & $\begin{array}{l}35.94 \\
2.52\end{array}$ & $\begin{array}{l}72.1 \\
89.2\end{array}$ & $\begin{array}{l}7.1 \\
2.1\end{array}$ & $\begin{array}{l}83.9 \\
80.9\end{array}$ & $\begin{array}{l}6.1 \\
9.1\end{array}$ \\
\hline $\begin{array}{l}\text { Mean: } \\
\quad \text { Pre-operative } \\
\text { Post-operative }\end{array}$ & $\begin{array}{l}27.6 \\
(19.3-35.9) \\
2.8 \\
(0.3-7.51)\end{array}$ & $\begin{array}{l}73.1 \\
(65.1-100) \\
87.6 \\
(86.6-89.2)\end{array}$ & $\begin{array}{l}5.6 \\
(4.1-7.1) \\
1.2 \\
(0.2-2.1)\end{array}$ & $\begin{array}{l}80.4 \\
(71.3-87.3) \\
79.1 \\
(74.4-82.1)\end{array}$ & $\begin{array}{l}9.6 \\
(2.7-18.7) \\
10.82 \\
(7.9-15.6)\end{array}$ \\
\hline
\end{tabular}

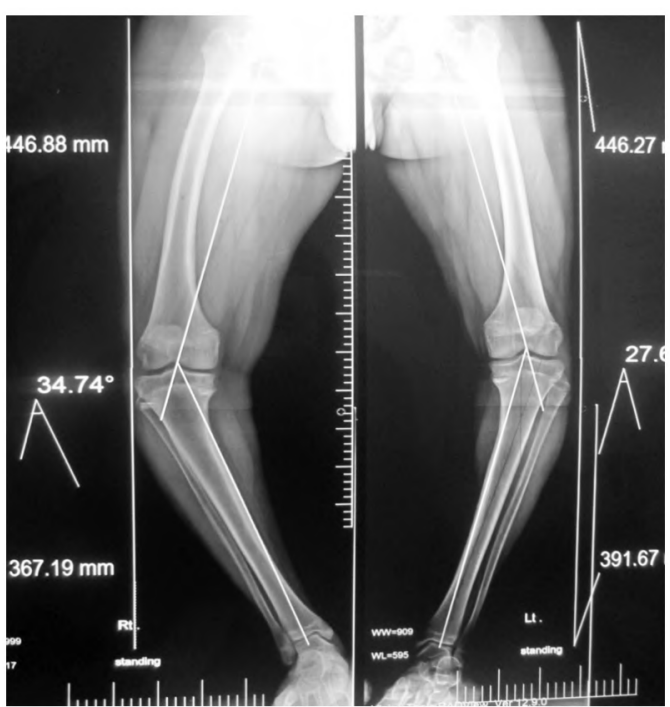

Fig. (1): Pre-operative standing AP X-ray of male patient aged 16 years old with bilateral moderate tibia vara. MTFA was $34.74^{\circ}$ at the right side and $27.6^{\circ}$ at the left side.

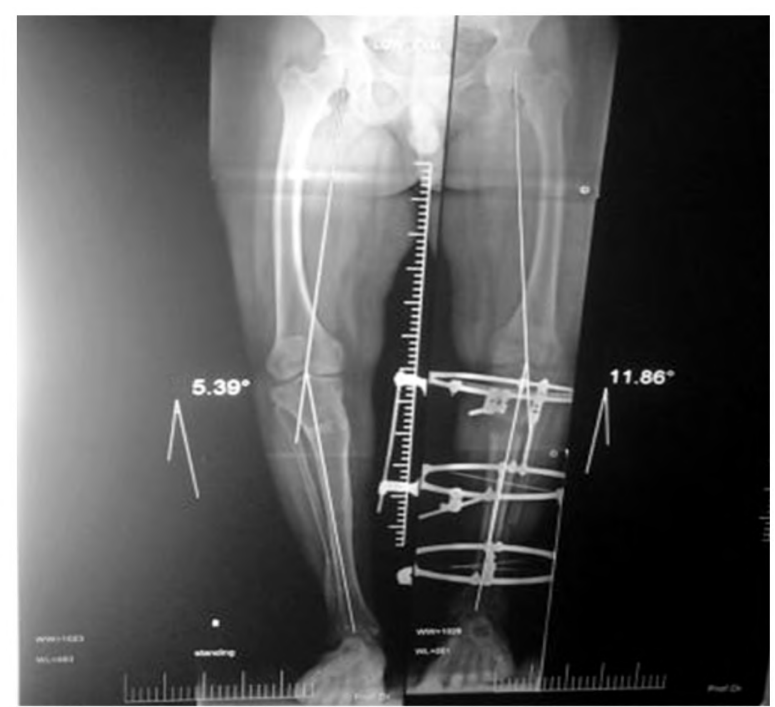

Fig. (2): Post-operative standing long X-ray which show the second stage left limb correction, the m-TFA (MA) became $11.86^{\circ}$, the distraction was continued for 21 days and JLCA was $5.8^{\circ}$ at the left side which was corrected to $1.3^{\circ}$. 


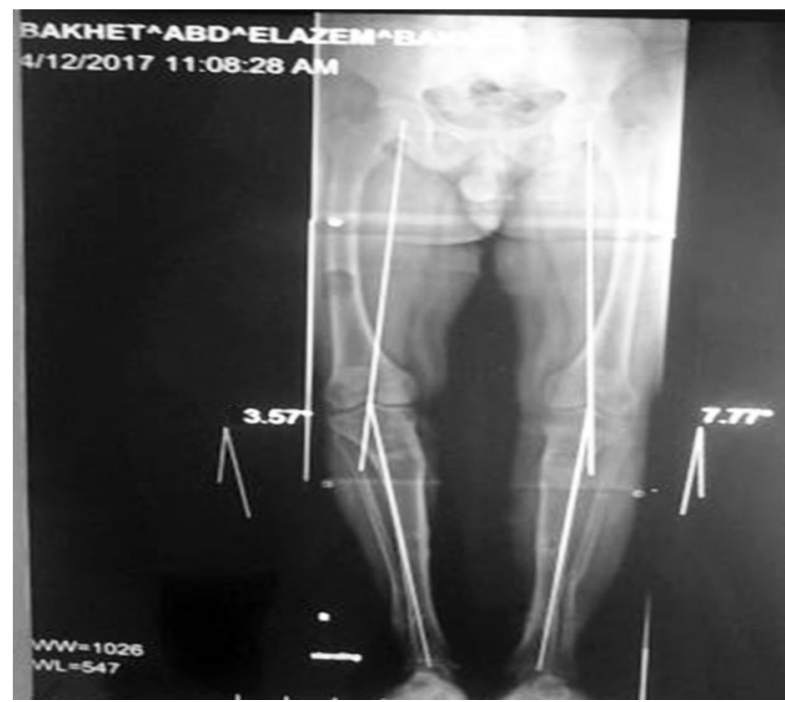

Fig. (3): The residual deformity was due to femoral attribute in the varus as the Lateral Distal Femoral Angle (LDFA) was $86^{\circ}$ at the right side and $100^{\circ}$ at the left side, and the patient needs further osteotomy at the distal femur.

\section{Discussion}

Adolescent tibia vara can be corrected either with acute correction such as, by proximal tibial osteotomy as medial based opening, lateral based closing wedge or dome-shaped osteotomy or by elevation of the medial tibial plateau. Acute correction may be associated with complications such as peroneal nerve palsy, compartment syndrome, limb length inequality, delayed union, and failure of fixation [4]. Residual deformity in form of overor under-correction due to inappropriate intraoperative alignment may result. Overcorrection should be avoided in adolescent tibia vara [5] Gradual correction of deformity can be achieved by lateral hemiepiphysiodesis [6], which is not practical in older patients with the main disadvantage of inability to correct the rotational deformity. Asymmetrical physeal distraction [7] or distraction osteogenesis using Ilizarov external fixator [5] were also described. Price, et al., in 1995 [7], and Stanitski, et al., in 1997, [3] used a uniplanar external fixator especially for isolated frontal one-plane deformities with satisfactory results. The advantages include easy application, adjustability, early weight bearing, the ability to lengthen the extremity, and avoiding a second operation to remove the hardware [8]. Feldman [9] presented the first report of using Taylor Spatial Frame (TSF) in the treatment of tibia vara with success in 19 patients (22 tibias). Hegazy et al., performed V-shaped proximal tibial osteotomy to correct both medial joint depression and proximal tibial varus at the same time acutely without graft and fix it with Ilizarov external fixator [4]. In the current study medial plateau depression was $<16^{\circ}$ and so our cases need not elevation of the medial plateau. Mayer et al conducted a retrospective review of 41 patients (51 limbs) who underwent correction of Blount disease with an Ilizarov external fixator or a Taylor Spatial Frame (TSF) by a single surgeon [10]. There was no difference in MPTA and MAD in patients treated with an Ilizarov frame versus a TSF. MPTA, MAD, and JLCA all significantly improved regardless of the underlying diagnosis or history of prior surgical intervention. The most common complication was superficial pin-site infection [11]. In this study the use of Ilizarov external fixator as it is cheaper in comparison to TSF which is expensive. Gradual correction by external fixation; because obesity, unequal limb lengths, and femoral deformity often are present in patients with Blount's disease, recommended by Bell, in 1993 [11], as well as, Coogan et al., in 1996 [12], the Ilizarov technique as ideally suited for correction of deformity, as well as lengthening if needed, in adolescent patients [8]. The Ilizarov method allows, the surgeon to perform, complex acquired deformity. But the technique can be difficult and time consuming compared with methods that involve use of a monolateral fixator [13]. Gordon et al., describe a comprehensive approach to late-onset Blount's disease. They simultaneously corrected the femoral varus by means of lateral distal hemi-epiphyseal stapling (if there was enough growth remaining) or with an osteotomy and blade plate, in order to avoid residual distal joint line obliquity which could possibly lead to degenerative joint disease. They corrected the femoral varus if it exceeded $5^{\circ}\left(\mathrm{LDFA}>95^{\circ}\right)$ [14]. As regarding the radiological assessment of formed callus. There was no cases with no visible callus. This may due to technique of osteotomy, close follow-up \& modification of daily rate of distraction, the flexibility of Ilizarov frame and encouraging patient for early weight bearing as possible. There was one case with definite little callus strands which connect between bone ends. There were nine deformities $(90 \%)$ with callus strands linking bone ends at least one third of bone width. Distal femoral varus osteotomy was needed for correction in one case as bilateral case in this study. In the present work, no transient or permanent neurological injury was noted. With acute correction, it has been reported that up to one third of patients can have transient or permanent neurologic injury [13]. The Ilizarov method allows, the surgeon to perform, complex acquired deformity. But the technique can be difficult and time consuming compared with methods that involve use of a monolateral fixator [9]. 


\section{References}

1- CANALE S.T.: Osteochondrosis or Epiphysitis and Other Miscellaneous Affections. In Canale ST (Ed). Campbell's Operative Orthopedics. Vol. 1. Ed 9. St Louis, CV Mosby, 857-922, 1998.

2- BLOUNT W.P.: Tibia vara: Osteochondrosis deformans tibiae. J. Bone Joint Surg., 19: 1-29, 1937.

3- STANITSKI D.F., SRIVASTAVA P. and STANITSKI C.L.: Correction of proximal tibial deformities in adolescents with the T-Garches external fixator. J. Pediatr. Orthop., 18: 512-7, 1998.

4- HENDERSON R.C., KEMP G.J. and GREENE W.B. Adolescent Tibia Vara: Alternatives for operative treatment. J. Bone Surg. [AM], 74: 342-50, 1992.

5- ARONSON J.: The biology of distraction osteogenesis Operative Principles of Ilizarov, 4: 50-1, 1991.

6- RAJACICH N., BELL D.F. and ARIMSTRONG P.: Pediatric application of the Ilizarov method. Clin. Orthop., 280: 73-5, 1992.

7- PRICE C.T., SCOTT D.S. and GREENBERG D.A.: Dynamic axial external fixation in the surgical treatment of tibia vara. J. Pediatr. Orthop., 15: 236-43, 1995.

8- ILIZAROV G.A.: The transoseous osteosynthesis: Theo- retical and clinical aspects of the regeneration and growth of tissue. New York: Springer, 1992.

9- MAYER S.W1, HUBBARD E.W., SUN D., LARK R.K. and FITCH R.D.: Gradual Deformity Correction in Blount Disease. J. Pediatr. Orthop. Dec., 23: 10.1097, 2016.

10- CHECKETTS R.G., MACEACHERN A.G. and OTTERBURN M.: Pin track infection and the principles of pin site care. In: De Bastiani A., Graham Apley A., Goldberg A. (Eds) Orthofix external fixation in trauma and orthopaedics. Springer, Berlin Heidelberg New York, pp. 97$103,2000$.

11- BELL D.F.: Treatment of adolescent Blount's disease using the Ilizarov technique, Op. Tech. Orthop., 3: 149$51,1993$.

12- COOGAN P.G., FOX J.A. and FITCH R.D.: Treatment of adolescent Blount disease with the circular external fixation device and distraction osteogenesis, J. Pediatr. Orthop., 16: 450-3, 1996.

13- GORDON J.E., KING D.J., LUHMANN S.J., DOBBS M.B. and SCHOENECKER P.L.: Femoral deformity in tibia vara. J. Bone Joint Surg. Am. Feb., 88 (2): 380-6, 2006.

14-AIRD J.J., HOGG A. and ROLLINSON P.: Femoral torsion in patients with Blount's disease: A previously unrecognized component. J. Bone Joint Surg. Br. Oct., 91 (10): 1388-93, 2009.

\section{تصحيح فحجاء عظمة الساق الظثبوبية عثد المراهقين بواسطة المثبت الحارجى (إليزاروف)}

عشرة أطراف سفلية من V مرضى (متوسط أعمارهم عا سنة) وعولج من روحاء عظمة ظنبوب الساق بواسطة جهاز الإليزاروف الدائرىى

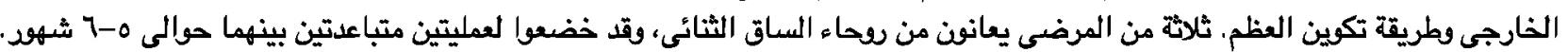

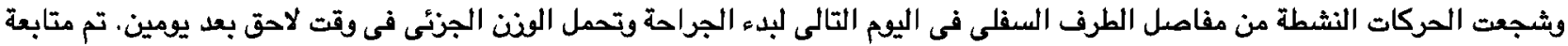

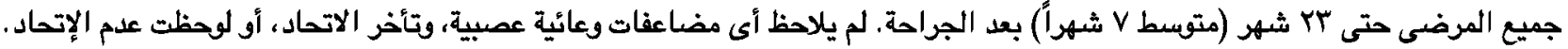

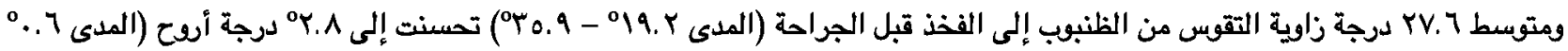

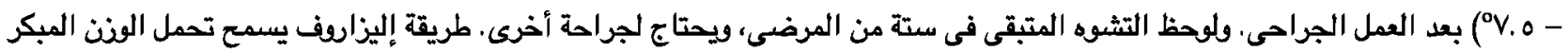

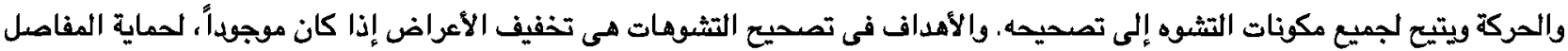

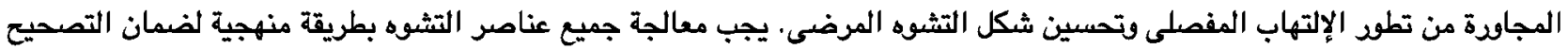

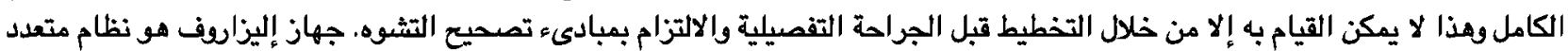

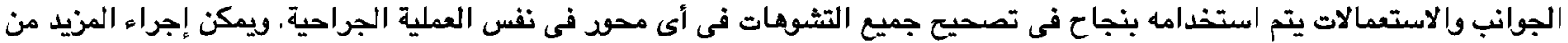

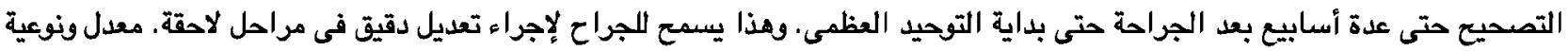

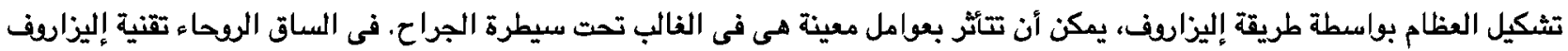

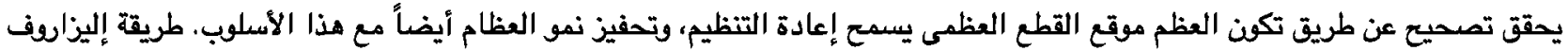

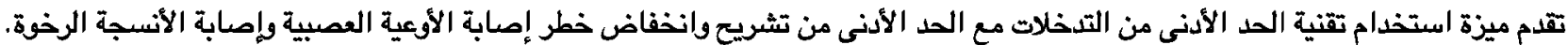

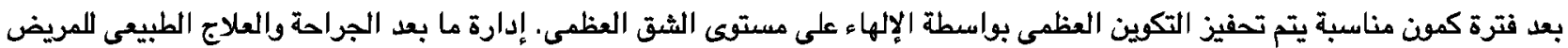

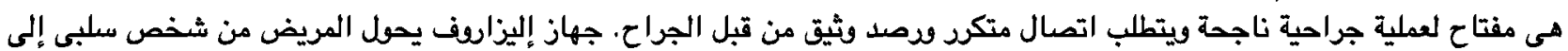
فرد نشط يساهم في تصحيح تشوه الساق بنفسه. 